\title{
AJI UGI: \\ PERGUMULAN ISLAM DENGAN TRADISI LOKAL DAN GAYA HIDUP DI MASYARAKAT BUGIS
}

\author{
AJI UGI: \\ THE ENCOUNTER OF ISLAM WITH LOCAL TRADITIONS AND LIFESTYLES \\ IN BUGINESE SOCIETY
}

\author{
Syamsurijal \\ Balai Penelitian dan Pengembangan Agama Makassar \\ Jalan AP. Pettarani No.72, Makassar \\ Email: bhatijalgol@gmail.com \\ Musafir Pababari \\ Universitas Islam Negeri Alauddin \\ Jalan Sultan Alauddin No.63 Romangpolong, Gowa \\ Email: musafir.pababari@uin-alauddin.ac.id. \\ Muhammad Ramli \\ Universitas Islam Negeri Alauddin \\ Jalan Sultan Alauddin No.63 Romangpolong, Gowa \\ Email: muhammadramli1960@gmail.com \\ Wahyuddin Halim \\ Universitas Islam Negeri Alauddin \\ Jalan Sultan Alauddin No.63 Romangpolong, Gowa \\ Email: wahyuddinh@hotmail.com
}

Naskah diterima tanggal 12 Maret 2020, Naskah direvisi tanggal 7 Mei 2020, Naskah disetujui tanggal 9 Juni 2020

\begin{abstract}
Abstrak
Haji adalah salah satu rukun Islam yang kelima. Umat Islam juga meyakini bahwa haji adalah ibadah yang pahalanya berlipat ganda. Tetapi dalam masyarakat Bugis, haji bukan semata-mata praktik ibadah dan ritual untuk memenuhi rukun Islam yang kelima. Haji juga terkait dengan ritual lokal, penanda status sosial, bahkan juga kini menjadi bagian dari gaya hidup. Penelitian dengan metode kualitatif di salah satu daerah Bugis, yaitu di Segeri kabupaten Pangkajene Kepulauan, menemukan corak haji orang-orang Bugis yang telah mengalami perjumpaan antara ajaran Islam, tradisi lokal dan modernitas. Perjumpaan ini melahirkan corak haji yang unik, sebab diekspresikan dengan caracara lokal di satu sisi, sekaligus dipengaruhi modernitas di sisi yang lain. Dalam ekspresi semacam itulah ditemukan praktik yang disebut Haji Bawakaraeng, Haji Calabai (Haji Waria) dan Haji Pa'gaya (Haji yang suka bergaya). Tetapi di saat yang sama juga ditemukan Haji yang sarat dengan nuansa hikmah, misalnya haji sebagai were na pammase (Haji sebagai takdir dan Rahmat Tuhan) dan haji sebagai assenu-senungeng (ritual haji adalah simbol pengharapan terhadap hal yang baik). Keseluruhan praktik haji semacam itu mencerminkan sebuah praktik keberislaman ala Bugis, yang disebut dengan “Aji Ugi”. Aji Ugi ini menjadi semacam ekspresi Islam lokal yang sekaligus universal, Islam tradisional sekaligus modern.
\end{abstract}

Kata Kunci: aji ugi, pergumulan, tradisi lokal, modernitas

\begin{abstract}
Hajj is one of the five pillars of Islam. Muslims also believe that the Hajj is a worship that has double rewards. But in the Bugis community, the Hajj is not merely a practice of worship and ritual to fulfill the fifth pillar of Islam. The Hajj is also associated with local rituals, symbols of social status, even
\end{abstract}


now it has become part of the lifestyle. This study uses a qualitative method in one of the Bugis areas, namely in Segeri, Pangkajene Kepulauan Regency, finding a Bugis hajj pattern that has experienced a encounter between Islamic teachings, local traditions and modernity. This encounter gave birth to a unique hajj style, because it was expressed in local ways on the one hand, at the same time influenced by modernity on the other. In this kind of hajj expression, there is a practice called Haji Bawakaraeng, Haji Calabai (Transgender Hajj) and Haji Pa'gaya (stylish Hajj) found. But also found hajj which is loaded with nuances of wisdom, such as haji were na pammase (hajj as God's destiny and grace) and haji assenu-senungeng (hajj ritual is a symbol of hope for good things). All of these hajj practices reflect Bugis style Islamic practices, called "Aji Ugi". Aji Ugi has become a kind of local Islam that is at once universal, becoming both traditional and modern Islam.

Keywords: aji ugi, encounter, local tradition, modernity

\section{PENDAHULUAN}

$\mathrm{N}$ aik haji ke Mekkah memang menjadi idaman setiap umat Islam. Tetapi di antara umat muslim itu, mungkin orang Bugislah yang memiliki minat yang paling tinggi. Setiap tahunnya antrean umat Islam untuk menunaikan rukun Islam yang kelima di daerah Bugis, bertambah panjang. Jika merujuk pada data haji Kementerian Agama Sulawesi Selatan (2018), dalam beberapa tahun terakhir, daftar tunggu paling lama terdapat di Sulawesi-Selatan. Di beberapa daerah Bugis, seperti, Wajo, Pinrang dan Sidenreng Rappang, daftar tunggu mengantre hingga 30 tahun lebih. Sebagai catatan, ant usiasme etnis Bugis dalam berhaji bukan baru sekarang. Dalam tulisan Jacob Vrendenbregt (1997: 97) disebutkan, pada rangkak abad IX-XX, ada 5 daerah yang paling tinggi intensitas perjalanan hajinya. Salah satunya adalah etnis Bugis atau Sulawesi secara umum, selain Jawa Barat, Sumatera Barat, Jawa Tengah dan Kalimantan Barat (Banjar).

Tingginya animo masyarakat Bugis naik haji ini bukan semata karena haji terkait dengan perkara ibadah dan ikhtiar menggenapkan rukun Islam. Tetapi haji juga terkait dengan tradisi lokal, status sosial dan bahkan terpaut dengan persoalan gaya hidup. Yang terakhir ini mulai menjadi gejala sampai di masyarakat pelosok akibat pengaruh modernisme. Dalam beberapa tahun belakangan modernisme memang telah diserap oleh masyarakat-masyarakat di Bugis sampai ke pelosok-pelosok kampung.
Dalam masyarakat Bugis, gelar haji bisa memastikan seseorang duduk di kursi terhormat dalam pesta atau rapat-rapat penting di kampung. Bergelar haji berarti petuahnya ditunggu, jika memberi pendapat suaranya disimak dan boleh jadi pandangannya menjadi kesimpulan dan penentu dalam sebuah pertemuan. Haji juga bisa menjadi jaminan dalam sebuah bisnis. Lapak yang dikelola oleh seorang yang bergelar haji apalagi jika nama lapaknya juga sudah diberi embel-embel haji, bisa lebih terkenal dan dikunjungi banyak orang dibanding toko lainnya.

Kadir Ahmad (2013: 165-176), menyebutkan dalam masyarakat BugisMakassar, sebagian masyarakat berikhtiar mendapatkan privilese sosial melalui status daeng aji, puang aji dan karaeng aji. Sebelumnya gelar kebangsawanan (arung), kepintaran (to acca) dan keberanian (to warani) menjadi penentu status sosial. Kini stat us sosial lebih terpandang lagi, jika sudah bercampur antara haji dan kebangsawanan. Karaeng Aji atau Puang Aji, jauh lebih mengesankan di banding hanya menggunakan stat us karaeng atau puang saja. Status-stat us haji apalagi bergabung dengan status kebangsawanan akan menentukan seseorang berada di panggung depan dalam sebuah hajatan.

Dalam catatan kalangan akademisi, sebutlah Shaleh Putuhena, misalnya, menyatakan pelaksanaan haji di Indonesia dan juga di belahan dunia lainnya, tidak bisa dilepaskan begitu saja dengan persoalan budaya, konteks sosial bahkan politik. Saleh Putuhena dengan terang mengatakan : "Haji 
sebagai peristiwa agama memiliki keterkaitan erat dan saling berpengaruh dengan peristiwa-peristiwa sosial, budaya dan politik dalam masyarakat"(Putuhena, 2007: 4). Dengan demikian haji adalah ibadah mahdah yang dipengaruhi dan mempengaruhi konteks budaya, sosial dan politik di masyarakat Saerozi (2008).

Pergulatan antara haji sebagai salah satu ajaran Islam dengan kehidupan sosialbudaya, memperjelas hubungan yang erat antara Islam sebagai agama universal dengan kebudayaan yang hidup di masyarakat. Hal ini lazim terjadi dalam cara-cara beragama umat Islam di Nusantara. Jika demikian maka pertautan antara haji dengan sosial-budaya masyarakat adalah hal yang lumrah dan biasa. Lalu apa yang berbeda dari pergumulan haji orang Bugis dengan tradisi lokal dan modernitas?

Dalam hal ini yang menarik dalam perayaan haji orang Bugis, karena peristiwa itu menjadi moment um perayaan tradisi lokal dan penabalan status sosial. Melalui haji, di beberapa masyarakat Bugis, ritual selamatan digelar dengan semarak. Melalui haji pula, sebagian orang menjadikannya momentum unt uk meraih posisi sosial tertentu. Karena itu jika di masyarakat tertentu, status sosial yang tinggi dan penghormatan masyarakat terhadapnya adalah efek positif dari haji, maka dalam sebagian masyarakat Bugis, haji berubah menjadi gaya hidup agar bisa eksis dalam kelompok elite tertentu di masyarakat.

Dalam beberapa hal kuatnya pengaruh budaya dan gaya hidup ini memberi imbas negatif dalam pelaksanaan haji orang-orang Bugis. Di antara mereka misalnya ada yang harus berurusan dengan pihak berwenang di Arab Saudi, karena kedapatan menggunting kiswah Ka' bah. Menggunting kiswah itu dilakukan karena kuatnya pengaruh kepercayaan yang berasal dari tradisi lokal yang mereka miliki (Liputan6.com, 2018).

Selain itu beberapa orang Bugis, karena saking kuatnya keinginan naik haji, memilih untuk mengikuti prosesi haji melalui layanan dari biro-biro haji yang tidak jelas. Mereka rela masuk dalam pasar gelap haji, demi memenuhi hasrat naik haji. Sering kali hasrat yang menggebu-gebu semacam ini, muncul dalam lingkungan sosial di mana haji telah menjadi ukuran gaya hidup kelas menengah muslim. Akhirnya muncullah kasus, beberapa jemaah haji terjebak dalam kasus penipuan Travel haji yang menggunakan bisnis model ponzi. Ada pula Jemaah Haji asal Bugis yang terdampar di Singapura, karena tertipu dengan paspor Filipina. Niat awal menuju Mekkah, apalah daya di Filipina jualah terdampar akhirnya.

Motivasi berhaji yang memanfaatkan kehajiannya tak lebih dari gaya hidup, tak pelak menimbulkan ungkapan-ungkapan satire terhadap mereka. Mereka disebut haji tellettu atau tembettu (tidak sampai), untuk mengejek perilaku haji semacam ini. Istilah ini konon memelesetkan istilah haji tamattu. Maksudnya bukan mengejek istilah tamattu itu sendiri, tetapi mengkritik hasrat haji yang menggebu-gebu tanpa memedulikan syaratsyarat yang ditentukan agama.

Sudah barang tentu pergumulan haji (Islam) dengan tradisi lokal dan modernitas tidak selamanya melahirkan hal-hal yang negatif. Perjumpaan itu juga melahirkan tradisi-tradisi yang baik dan mendekatkan ajaran Islam yang bernama haji ini ke tradisi lokal atau kebudayaan yang dipahami masyarakat. Pergumulan yang muncul dalam proses berhaji ini, menunjukkan pula hubungan antara Islam dan tradisi lokal yang saling mengisi dan melengkapi, tanpa ada satu entitas yang mendominasi dan lebih determinan dibanding yang lainnya.

Proses pergumulan inilah yang memunculkan satu model perjumpaan antara haji, tradisi lokal dan modernitas, yang kemudian disebut 'Aji Ugi'. Tulisan ini akan mencoba menggambarkan proses pergulatan tersebut. Menguraikan bagaimana Islam melalui haji berjumpa dengan tradisi lokal Bugis di satu sisi dan modernitas di sisi yang lain.

\section{TINJAUAN PUSTAKA}

Hubungan yang erat antara haji dengan tradisi lokal telah diulas oleh banyak peneliti. Di antaranya adalah Shaleh Put uhena (2007), Chambert Loir (2013), Emsoe Abdurrahman (2016), dan Kadir Ahmad (2013). Kadir Ahmad dalam soal perjumpaan haji dengan kebudayaan dan konteks sosial masyarakat mengatakan: 
Dengan kata lain, meskipun haji adalah bagian dari ajaran yang oleh orang Islam dipahami sebagai bagian dari perintah Allah, bukan dari manusia, namun ketika ajaran itu sudah bersentuhan dengan manusia, maka pada waktu yang sama ia lalu menjadi bagian dari kebudayaan (Ahmad, 2013: 176).

Perjumpaan Haji dan Modernitas di Bugis juga telah diurai dalam tulisan Asma Luthfi (2006) dan Hartini Tahir (2016). Tulisan Asma Luthfi mengulas tentang pengaruh modernitas terhadap haji yang berada di beberapa daerah di Bugis, sementara Hartini memperlihatkan bagaimana Haji dan Umrah telah menjadi gaya hidup dalam masyarakat kelas menengah muslim. Asma Luthfi sendiri kendati mengulas soal modernitas secara umum sehingga memunculkan, dalam istilah Dia: "Aji Modereng", tetapi pada dasarnya, selaras dengan Hartini Tahir, Asma Luthfi juga mengulas soal haji yang telah berubah menjadi gaya hidup. Tulisan dalam artikel ini sendiri juga akan mengulas soal pengaruh haji sebagai gaya hidup masyarakat Bugis, tetapi bukan menjadi satu-satunya fokus bahasan. Haji sebagai gaya hidup itu hanya dilihat sebagai bagian dari perilaku haji orang Bugis, di samping beberapa praktik haji lainnya yang khas, sebagai akibat dari pergumulan antara ajaran Islam, tradisi lokal dan modernitas.

Pertautan antara haji dan konteks sosial-budaya masyarakat adalah sebagian kecil dari bukti bahwa antara Islam, sebagai agama, dengan konteks sosial-budaya di Indonesia telah mengalami pergumulan yang panjang dan intens. Kajian-kajian yang memperlihatkan intensitas pergulatan itu, juga telah berkembang sedemikian rupa. Mulai dari yang melihat hal ini sebagai proses asimilasi, akulturasi, dan juga yang melihatnya sebagai sinkretisme.

Tulisan ini memilih satu perspektif yang disebut dengan encounter. Perspektif ini sejauh yang penulis telusuri, belum banyak digunakan dalam melihat perjumpaan antara haji dengan tradisi lokal maupun dengan modernitas. Encounter tidak persis sama dengan asimilasi ataupun akulturasi. Dalam asimilasi maupun akulturasi proses 22 | Jurnal “Al-Qalam” Volume 26 Nomor 1 Juni 2020 perjumpaan dilakukan dengan terlebih dahulu entitas atau kebudayaan kecil melepas karakter khasnya. Setelah itu barulah tradisi besar (universal) bisa mengakomodasi tradisi kecil (Gordon, 1964).

Sementara dalam proses encounter, tidak ada entitas yang harus kehilangan nilai terlebih dahulu. Proses pergulatan itulah yang menentukan, yang mana yang harus bertahan dan yang mana harus ditanggalkan. Penentuan yang mana harus dipertahankan dan ditinggalkan, bukan ditentukan oleh tradisi besar (universal), tetapi ditentukan oleh daya guna dan vitalitas masing-masing nilai dalam konteks tertentu.

Bikhu Parekh (2000: 250), avantgarde kajian Multikulturalisme, memuat tiga hal dalam konteks encounter yang berujung pada apa yang kita sebut masyarakat multikult ural:

Pertama; Manusia terikat secara kultural dalam kebudayaan dimana ia tumbuh dan berkembang. Kendati demikian, hal ini tidak mengandaikan bahwa yang bersangkutan tidak bisa mengevaluasi dan beranjak dari nilai-nilai kultur yang membentuknya. Perjumpaan dengan entitas (kebudayaan) yang berbeda memberi peluang pada seseorang untuk memikirkan ulang kebudayaan di mana mereka tumbuh dan berkembang.

Kedua; Kebudayaan yang puspa rupa mencerminkan sistem makna yang baik dan jalan hidup yang beragam. Semua kebudayaan, dengan demikian, harus dinilai sebagai sesuatu yang berharga atau setidaknya tidak ada kebudayaan yang secara keseluruhannya tidak bernilai. Tetapi daya jangkau kebudayaan itu tidak mampu menggenggam secara totalitas segenap eksistensi manusia. Di sinilah ia memerlukan yang lain.

Ketiga; Kebudayaan adalah refleksi dari dialog yang kontinu dari berbagai tradisi dan ajaran yang ada. Budaya, tak terkecuali Islam dan juga tradisi Bugis, tumbuh dan dibentuk atas interaksinya dengan yang lain. Setiap entitas budaya membawa bagian dari kebudayaan-kebudayaan yang lain. Hal ini tidak mengandaikan bahwa satu komunitas 
budaya nir-identitas, namun identitas itu bersifat plural dan terbuka.

Sementara itu terkait dengan ritual selamatan yang marak pula dipraktikkan dalam tradisi haji orang-orang Bugis, telah banyak diamati oleh berbagai kalangan. Di antaranya Van Gennep (1960) yang menyebut sebagai rites of passage atau ritual peralihan. Disebut demikian karena ritual selamatan, termasuk yang dilakukan saat berhaji, adalah sebuah penanda perpindahan seseorang dari tahap kehidupan yang satu ke tahap yang lain. Dalam haji bisa dianggap sebagai perpindahan dari tahap sebagai manusia biasa menjadi muslim yang lebih paripurna.

Adapun persoalan gaya hidup, juga telah diulas oleh banyak sosiolog, antara lain oleh Assael dengan mengatakan bahwa gaya hidup adalah:

A mode of living that is identified by how people spend their time (activities), what they consider important in their environment (interest), and what they think of themselves and the world around them opinion (Assael, 1984:252).

\section{METODE PENELITIAN}

Artikel ini merupakan kepingan dari sebuah penelitian disertasi yang cukup panjang. Penelitian dilakukan dengan pendekatan kualitatif. Burhan Bungin menyebutkan penelitian kualitatif mengandalkan wawancara mendalam dan observasi (Bungin, 2006:47). Penelitian ini telah menerapkan hal tersebut dengan melakukan wawancara mendalam terhadap tokoh agama, petugas haji di Kementerian Agama Pangkajene Kepulauan, para haji dan bahkan masyarakat umum di seputar Segeri. Selain itu peneliti juga melakukan observasi dengan mengamati berbagai ritual lokal yang terkait dengan haji. Dalam mengamati berbagai upacara tersebut, penulis mencoba menginterpretasikannya dengan meminjam cara Gertz yaitu dengan cara thin description dan thic description. Praktik haji dengan berbagai ritualnya diamati secara permukaan dan di saat yang sama juga menggali maknanya secara mendalam (tebal) (Geertz, 1973: 140-147).
Mengapa memilih Segeri- Pangkajene Kepulauan (selanjutnya disebut Pangkep) untuk melihat praktik haji orang-orang Bugis? Tidak lain karena di Segeri upacara-upacara lokal Bugis serta ritual lokal yang terkait dengan haji masih intens dilakukan. Selain tentunya karena Segeri adalah salah satu daerah dengan minat berhaji yang cukup tinggi dari masyarakatnya.

\section{PEMBAHASAN}

\section{Selintas Sejarah Haji di Segeri}

Kecamatan Segeri terletak di bagian utara kabupaten Pangkep. Letaknya dekat dengan Barru. Kecamatan ini dengan Barru hanya diantarai oleh Kecamatan Mandalle. Konon istilah Segeri, seperti dijelaskan oleh Puang Ali, ketua adat di daerah ini, berasal dari kata Sigerra-gerra (saling adu mulut) dan sigere-gere (saling membunuh). Hal ini berkenan dengan kondisi daerah kala itu yang merupakan daerah suram. Pada abad-abad ke 12, situasi daerah ini masih chaos, sering sekali terjadi perkelahian dan pertengkaran. Pada masa itu orang-orang masih sianre bale, yang kuat memangsa yang lemah. Jagoan petantang-petenteng menjadi penguasa wilayah. Suasana yang kelam ini, nanti tersibak dengan kedatangan seorang haji yang dikenal dengan nama Puang Ajji Sayye. Tidak terlalu jelas siapa Puang Aji Sayye ini, tetapi menurut Puang Ali, dia adalah salah satu di antara orang-orang yang pernah belajar di Pulau Salemo. Puag Ajji Sayye ini ada pula yang mengatakan keturunan Datuk Sabutung yang bernama Sayyid Jaffar. Jika yang dimaksudkan Puang Aji Sayye ini adalah Sayyid Jaffar, maka Ia datang ke daerah ini sekitar tahun 1488. Memerintah di daerah ini mulai dari tahun 1488 sampai pada tahun 1545 (Wawancara Puang Ali, 2017).

Menurut data Pangkep Dalam Angka (2019) penduduk di daerah ini berjumlah sekitar 19.556 Pertanian di daerah ini meliputi sawah, kebun sayur, jeruk dan juga tambak. Keempat hal itulah yang menjadi sumber penghidupan utama masyarakat Segeri. Beberapa warganya ada pula yang bekerja sebagai pedagang at aupun PNS, tetapi jumlah mereka tidak sebanyak yang berprofesi petani tadi. 
Di daerah Segeri adat masih kental dianut oleh masyarakat. Adat-istiadatnya berbasis pada tradisi pertanian (agriculture tradition). Banyak ritual yang digelar bersandar pada tradisi pertanian. Salah sat unya adalah mappalili. Ritual ini dilakukan sebelum mulai menggarap sawah. Ritual lain yang berkembang yaitu ritual yang terkait dengan siklus hidup manusia dan ritual tradisi yang terkait dengan agama. Ritual terkait agama yang paling marak dalam hal ini dan banyak rangkaiannya adalah ritual haji. Hal ini terkait dengan banyaknya orang yang berhaji dan banyak tahapan dalam haji itu yang perlu dibuatkan ritual.

Maraknya tradisi dan ritual lokal di daerah ini ditopang oleh keberadaan Bissu. Bissu ini adalah ahli spiritual Bugis. Kebanyakan mereka adalah calabai (waria). Bissu inilah yang banyak memimpin upacaraupacara adat dan berbagai ritual lokal. Di Segeri terdapat arajang, pusat Bissu melakukan kegiatan (Lathief, 2004: 66).

Kuatnya tradisi lokal di Segeri ini sangat mempengaruhi berbagai ritual yang terkait dengan haji. Itulah sebabnya Segeri ini yang menarik perhatian penulis ketika akan mengangkat pergumulan Islam dan tradisi lokal melalui salah satu ajaran Islam yaitu haji. Jumlah haji di Segeri tiap tahunnya lumayan banyak, meskipun bukanlah kecamatan yang memiliki haji paling tinggi. Jumlah jemaahnya haji Segeri bukan yang tertinggi, karena jumlah penduduknya juga tidak banyak. Di banding beberapa kecamatan lain, misalnya Bungoro yang memiliki 44.679 penduduk, jumlah penduduk Segeri memang terbilang tidak terlalu besar (Pangkep Dalam Angka, 2019).

Pada masa kerajaan Siam, tahun 1542, Islam sudah ada di kerajaan ini, hal itu terbukti dengan adanya dialog seorang misionaris Antonio de Veipa dengan raja Siam saat itu. Dalam dialog itu disebutkan bahwa umat Islam sudah ada sejak 50 tahun yang lalu, jadi sekitar tahun 1498 (Andaya, 2004).

Jika tahun itu Islam sudah ada di Pangkep, maka bisa diperkirakan bahwa pada tahun-tahun tersebut juga sudah ada haji di daerah ini. Mengingat para kaum muslim yang ada di kerajaan Siam saat itu adalah para pedagang yang berasal dari luar, yaitu dari Gujarat dan daerah Timur-Tengah lainnya. Namun kemungkinan haji-haji dari masyarakat lokal sendiri belum ada. Rentang tahun 1900-1955 barulah dikenal pesantren di Pulau Salemo-Pangkep. Ulama-ulama yang ada di tempat inilah yang kemudian mengajarkan ilmu-ilmu agama di seputar Pangkep dan beberapa daerah lainnya. Rentang tahun itu juga sudah mulai banyak orang-orang Pangkep yang berhaji.

Sementara itu, seorang tokoh yang bernama Puang Aji Sayye dikenal oleh masyarakat Segeri sebagai haji pertama di daerah Segeri. Jika yang dimaksud Puang Aji Sayye ini adalah Sayyid Ja'far, maka Ia masuk ke Segeri dan memerintah di daerah ini sejak tahun 1448. Jika ini yang jadi sandaran, maka tahun 1448 sudah ada haji di Segeri. Tentu hajinya bukan asli orang Bugis-Segeri, karena Sayyed Jaffar adalah pendatang dari Timur Tengah yang kemudian menetap di daerah ini. Sampai saat ini keturunan Sayyed Jafar ini masih ada di daerah Segeri.

Informasi dari beberapa haji tua, misalnya Puang Supu, menyebutkan, orangorang Segeri sendiri mulai berhaji sekitar abad ke-19. Menurut cerita yang didengar dari orang tuanya, Haji Baco, orang sudah berhaji di Segeri saat belum ada transportasi pesawat. Adapun transportasi pesawat ini mulai muncul pada tahun 1951. Dengan demikian sebelum tahun itu sudah ada orang Segeri yang melaksanakan haji.

Pada tahun 1898, hanya Batavia dan Padang yang dijadikan pelabuhan haji. Makassar sendiri nanti pada tahun 1922, baru dijadikan pelabuhan haji. Dengan demikian diperkirakan orang Segeri dan Pangkep pada umumnya mulai berangkat haji pada tahun 1922 ini. Tentu dengan jumlah yang masih sedikit. Mengingat pada tahun-tahun itu pemberangkatan Jemaah haji masih menggunakan kapal barang (Abdurrahman, 2016).

Haji Baco, orang tua dari Puang H.Supu, berangkat ke Tanah Suci dengan menggunakan kapal barang. Ia berangkat selama tiga bulan. Perjalanan ke Mekkah memakan waktu tiga minggu, begitu pun waktu pulang. Ia harus membawa bekal dua 
peti besar. Selama dalam perjalanan, H.Baco menanggung kesulitan yang tak tanggungtanggung. (Wawancara H. Supu, 2017).

Pada awal-awal orang Pangkep berhaji, ritual-ritual selamatan (Rites of Passage) jauh lebih semarak dan sakral. Hal ini terkait dengan perjalanan haji yang dianggap sebagai perjalanan panjang dan berat. Orang yang pergi berhaji sudah dilepas sedemikian rupa, termasuk kemungkinan tidak kembali lagi ke Toddangnge (Tanah Air). Selain itu, Jemaah haji saat itu rata-rata serius mattareka (mempelajari) haji, baik lahir dan rahasianya. Hal ini karena berhaji pada saat itu adalah hal-hal yang betul-betul misterius dan tidak bisa dibayangkan apa yang akan terjadi di sana.

\section{Latar Belakang Sosial Jemaah Haji dan Perkembangannya Beberapa Tahun Terakhir di Segeri}

Sebagaimana telah dikemukakan sebelumnya, jumlah jemaah haji di Segeri cukup menonjol, kendati bukanlah yang terbanyak di kabupaten Pangkep. Tahun 2017, misalnya, jemaah haji dari Segeri sebanyak 53 orang, sementara yang mendaftar tahun tersebut sebanyak 120 orang. Sementara tahun 2018 sebanyak 46 dan di tahun 2019 menurun menjadi 26. Penurunan ini bukan karena minat berhaji orang Segeri menurun, tetapi karena adanya pembatasan jumlah kuota haji (Seksi Haji Kemenag Pangkep, 2018)

Masyarakat Segeri rata-rata bekerja sebagai petani kebun atau pun tambak, hal ini pun tergambar dari mayoritas haji di daerah ini yang kebanyakan pekerjaannya adalah petani. Mengenai data pekerjaan petani ini, penulis hanya mendapatkan data di tingkat kabupaten Pangkep, dimana data jemaah haji tahun 2016, misalnya disebutkan, rata-rata pekerjaan mereka adalah bertani atau Ibu Rumah Tangga (IRT). Jumlah petani sebanyak 23 orang ditambah dengan IRT sebanyak 101 orang (Seksi Haji Kemenag Pangkep, 2018). Mungkin muncul pertanyaan, mengapa dari data tergambar IRT lebih tinggi dari petani? Menurut Kepala KUA Segeri, hal itu tak lain karena kebanyakan ibu-ibu yang mendaftar haji memasukkan jawaban IRT dalam kolom pekerjaan, padahal jika ditelusuri, ternyata biaya hidup, bahkan ongkos naik haji mereka berasal dari pertanian.

Kendati data-data tersebut adalah data kabupaten Pangkep secara keseluruhan, tetapi seturut dengan penjelasan Kepala KUA Segeri. H. Basir, hal itu juga merupakan gambaran dari pekerjaan rata-rata jemaah haji di Segeri. Malah menurut H. Basir, jumlah haji yang bekerja sebagai petani, persentasenya jauh lebih tinggi di Segeri.

Dari sisi pendidikan, haji di Segeri juga rata-rata berpendidikan Sekolah Dasar. Setidaknya begitulah yang tercermin dari data jemaah haji dalam beberapa tahun terakhir. Sebagai contoh (sekali lagi ini adalah data tingkat kabupaten), dalam data jemaah haji 2015 tercantum ada 111 berpendidikan SD. Sementara di tahun 2016, ada 105 jemaah haji yang juga berpendidikan SD (Seksi Haji Kemenag Pangkep, 2018). Seperti halnya dalam hal pekerjaan, dalam soal pendidikan, data tingkat kabupaten adalah cermin dari data pendidikan jemaah haji di Segeri. Hal ini dikonfirmasi oleh Kepala KUA Segeri dan beberapa Kepala Desa di Segeri. Salah satu dari kepala desa itu adalah A. Makmur, Ia memastikan pendidikan para haji di Segeri rata-rata adalah SD.

Haji di Segeri, dengan demikian, adalah orang-orang yang rata-rata bekerja di sektor pertanian, kebanyakan pendidikannya SD dan tinggal di desa-desa. Bisa dikatakan bahwa rata-haji di Segeri ini berlatar belakang agraris dengan kebudayaan-kebudayaan desa dan pertanian yang sangat mempengaruhi kehidupan sehari-harinya.

Lat ar belakang agraris dan desa inilah, salah satu alasan, mengapa jemaah haji di Segeri ini yang paling marak ritual lokalnya mengiringi prosesi pelaksanaan haji. Tentu hal ini ditunjang pula dengan keberadaan komunitas lokal semacam Bissu di daerah ini. Khusus ritual yang terkait haji, masyarakat di daerah ini melaksanakan ritual dalam beberapa tahapan; sebelum pemberangkatan, selama di Tanah Suci dan saat sudah kembali ke Tanah Air. Perayaan tersebut dilakukan dengan semarak dengan alat-alat ritual yang lumayan lengkap.

Mengapa masyarakat yang berlatar belakang rural-agraris ini intensitasnya begitu tinggi dalam pelaksanaan ritual dalam berhaji? Tidak lain, karena di masyarakat 
desa dan petani, sebelumnya sudah terbiasa melakukan berbagai macam ritual. Dalam hal bertani, misalnya, mereka selalu memulai terlebih dahulu dengan ritual tertentu sebelum turun ke sawah dan sebelum memanen hasil pertaniannya. Kebiasaan ini juga merembet ke hal-hal yang terkait dengan agama, misalnya dalam ritual haji.

Khusus masyarakat Segeri, ritual yang sering dilakukan dalam kaitannya dengan persoalan pertanian dikenal dengan nama mappalili. Ritual ini dilakukan sebelum proses menanam padi dilakukan. Sementara menjelang panen padi mereka melakukan ritual mappadekko. Upacara ini dilakukan di rumah arajang, dipimpin oleh Bissu. Kebiasaan inilah yang kemudian diintegrasikan ke dalam berbagai perayaan keagamaan, misalnya Maulid (mammaudu), Perayaan Asyura (mappeca sure), dan juga ritual saat prosesi haji.

Beberapa antropolog terkemuka sudah sejak dulu menyatakan bahwa dalam masyarakat desa dengan latar belakang agraris, banyak sekali ritual yang dilakukan oleh masyarakatnya. Hal ini misalnya telah dikemukakan oleh Koentjaraningrat (2007) Ketika memaparkan temuan-temuan antropolog klasik semacam Hertz, Van Gennep dan lainnya. Gertz dalam Agama Jawanya yang terkenal itu, telah mengudarkan pula hal ini secara gamblang. Beragam ritual tersebut lazim disebut slametan. Istilah Gertz ini mengambil dari istilah Jawa. Sementara di Bugis disebut dengan assalama. Ritual ini mengitari kehidupan petani dalam: siklus kehidupan (life cycle), siklus pertanian (Cycle of Agriculture), perayaan keagamaan termasuk haji di dalamnya, dan juga yang berkaitan dengan integrasi sosial (Social integration) (Geertz, 2017: 31)

Selain karena terbiasa melakukan ritual, masyarakat Segeri merasa penting melakukan ritual dan upacara selamatan terkait dengan haji, karena peristiwa ini adalah sebuah proses perpindahan ke tahap yang lebih tinggi dalam hidup manusia. Setelah menjadi haji, seseorang dianggap telah mengalami perpindahan dari tahap tau (manusia biasa) menjadi tau tongeng-tongeng (manusia sejati). Bahkan mungkin setelah berhaji, manusia bisa sampai pada tatataran tau mabettu (Insan Kamil). Tahapan perpindahan itu harus diupacarakan dan wajib digelarkan ritual agar yang bersangkutan sukses melewati proses peralihan tersebut. Inilah yang diistilahkan Van Gennep (1960), sebagai rites of passage (ritus peralihan).

\section{Haji dalam Tilikan Orang Bugis dan Ritual- Ritual Lokal}

Makna haji yang dikenal secara umum adalah perjalanan ke Baitullah dalam rangka melaksanakan ibadah dan sekaligus menunaikan rukun Islam yang kelima. Merujuk ensiklopedi Islam, arti haji adalah mengunjungi, menyengaja atau menuju (Ensiklopedi Islam, 1997: 61). Makna syara'nya, seturut pengertian Nurudin Atir, sebagaimana dikutip oleh Husnan Bey Fenanie, adalah menuju ke Baitullah dan tempat-tempat tertentu untuk melaksanakan ibadah-ibadah tertentu pula (Fenanie, 2010: 87).

Sementara di Bugis, makna haji di masyarakat, selain dalam makna syar'inya, juga muncul pemaknaan lain. Pemaknaan ini adalah buah dari pergumulan haji dengan tradisi setempat. Di antara makna haji menurut pandangan masyarakat Bugis, dapat dikemukakan antara lain:

Pertama; Haji sebagai ibadah dan memenuhi rukun Islam yang kelima. Inilah pandangan umum yang terdapat dalam masyarakat Bugis, termasuk di Segeri. Salah seorang, haji dan juga tokoh agama di daerah ini, H. Kasim Tobo menyatakan haji juga adalah ibadah puncak bagi seorang muslim. Karenanya seorang yang sudah melaksanakan haji seharusnya mencapai tingkat spiritual yang lebih baik dan perilaku yang lebih menawan. Seorang haji harus sampai pada tingkat tau mabettu (Insan Kamil) atau setidaknya tau tongeng-tongeng (Manusia Sejati). "Apanna rupanami tau tapi depa nancaji tau tongeng-tongeng, nepa naessa hajinna" (Jika hanya fisiknya saja manusia, tapi belum menjadi manusia sejati lahir dan batin, maka belumlah sah hajinya) 
Makna haji yang semacam ini pada umumnya dianut oleh umat Islam, tetapi bagi orang Bugis, ada beberapa hal yang membuat haji sebagai ibadah dan pemenuhan rukun Islam yang kelima ini bisa terpenuhi. Karena itu tidak cukup hanya sampai pada definisi haji sebagai ibadah, orang Bugis juga memberi makna lanjutan terhadap haji ini. Karena itu muncullah makna kedua dari haji ini yaitu haji adalah were na pammase. Puang Supu ketua adat Segeri yang berhaji pada tahun 2017 memberi penjelasan soal were na pammase ini. Menurutnya, dia belum bisa niak haji bukan karena tidak mampu, sebab dia punya tambak dan sawah yang luas, tetapi karena belum were.

"Di sinilah saya menyadari bahwa untuk menunaikan haji, tidak mungkin akan terlaksana tanpa ada were na pammase. Nappani engka were na pammaseku menre mekkah (Baru kini ada were dan pammase yang menghampiriku untuk naik di tanah suci).” Begitu penjelasan Puang Supu.

Haji yang berkenaan were na pammase ini sering sekali disebut-sebut oleh masyarakat segeri dan Bugis lainnya. Kadang-kadang ada ungkapan; Tania weremu na degage pammasena puang'e menre Mekkah. (Engkau tidak memiliki were dan pammase dari Allah SWT untuk naik haji).

Asma Luthfi yang melakukan penelitian haji di masyarakat Bugis-Barru juga menemukan istilah ini. Misalnya disebutkan oleh Asma: "Wereku' mi kasi'E naweddingka' menre tana marajaE" (Hanya karena were'ku (anugerah dari Atas) yang menyebabkan saya bisa naik Tanah Suci) (Luthfi, 2006: 70).

Istilah were na pammase bisa ditemukan dalam hampir seluruh relung kehidupan masyarakat Bugis. Tidak hanya yang berkenan dengan haji. Hanya saja dalam praktiknya, pada ibadah hajilah istilah were na pammase ini selalu dikaitkan. Karena itu haji dalam masyarakat Bugis ini seakan identik dengan were na pammase. "Tidak akan ada haji, tanpa ada were na pammase", begitu kira-kira kalimat yang bisa menggambarkannya.

Were sendiri dalam bahasa agama bisa sejajar dengan makna takdir. Kata were biasanya disandingkan dengan pammase, yakni rida atau rahmat dari Allah. Tetapi were na pammasse ini perlu ditunjang oleh usaha yang sungguh-sungguh. Dalam ungkapan orang Bugis disebut resopa temmangingi namalomo naletei pammasena dewatae (kerja keras tanpa putus asa akan mendapatkan kemudahan atas rahmat dari Tuhan Yang Kuasa). Dengan demikian were, pammasse dan resopa adalah tritunggal filosofi orang Bugis dalam mewujudkan citacita, terutama dalam hal ini untuk bisa memenuhi pelaksanaan ibadah haji.

Istilah were dan pammasse sudah dikenal oleh masyarakat Bugis sebelum datangnya Islam. Konon ungkapan "resopa temmangingi..." tadi diucapkan oleh Nenek Mallomo, seorang bijak bestari dari kerajaan Sidenreng, jauh sebelum Islam tiba di masyarakat Bugis. Filosofi orang Bugis ini menunjukkan sikap rendah hati dan selalu meyakini adanya faktor takdir di luar kemampuan manusia yang menjadi penentu mereka dalam meraih cita-cita. Setelah kedatangan Islam, filosofi orang Bugis ini mengalami perjumpaan dengan ajaran Islam, khususnya yang terkai dengan soal takdir.

Sampai di sini, penulis teringat dengan ungkapan seorang sufi bijak Ibn Atha'illah as-Sakandari yang sangat erat kaitannya dengan filosofi were na pammase orang-orang Bugis. Katanya, sebagaimana dikutip Ulil Abshar Abdalla: "sawaabiqul himami laa takhriqu aswaaral aqdaari".(Keinginan kuat mencapai sesuatu yg sudah dirancang dari awal tidak bisa menumbangkan tembok kepastian/were dari Tuhan) (Abdalla, 2019: 15).

Selain were na pammase, haji juga sering dimaknai oleh orang Bugis sebagai dalle. Inilah makna ketiga haji bagi orang Bugis. Haji sebagai dalle menunjukkan posisi haji yang identik dengan rezeki. Di tengah masyarakat Bugis, misalnya, sering kita dengar istilah" degaga dallena, na de' namenre ajji" (Tidak ada rezekinya sehingga belum bisa melaksanakan haji).

Haji sebagai dalle ini menggaris bawahi dua hal. Pertama; orang baru bisa naik haji di tanah suci, jika ada dale-nya (rezki). Puncak dari dalle tersebut adalah ketika seseorang telah bisa melaksanakan haji. Kedua, karena ukuran keberhasilan bagi orang Bugis adalah naik haji, maka seseorang akan giat mencari dalle. 
Dalam pengertian kedua, dalle menjadi semacam motivasi mencari rezeki agar bisa naik haji. Selintas dalam kaitannya antara motivasi mencari dalle dengan naik haji di sini mirip dengan konsep Etika Protestan yang diuraikan Max Weber (1930). Dalam hal ini Weber menyebut bahwa beberapa Etika Protestan Calvinis, mendorong etos kerja kapitalisme, yaitu keinginan untuk mengakumulasi modal, uang dan rezeki sebanyak-banyaknya. Di sini juga terlihat etos kerja orang Bugis dipengaruhi oleh keinginan untuk naik haji. Dengan kata lain agama berperan membangun etos kerja orang Bugis. Bedanya, dalam masyarakat BugisSegeri, sebagaimana peneliti amati, haji hanya sekedar menjadi motivasi untuk bekerja keras tetapi tujuannya bukan untuk mengakumulasi kekayaan. Hasil dari kerja kerasnya itu hanya diharapkan untuk ongkos naik haji. Berkenan dengan hal ini, H. Amirah, seorang pedagang perempuan yang telah berhaji di Segeri meringkasnya dengan kalimat; "De na parellu maega ladde doi, yang penting puratona lao ri butta marajae (Tidak perlu memiliki terlalu banyak uang, yang paling penting saya sudah menunaikan ibadah haji).

Makna haji yang keempat bagi orangorang Bugis adalah assennu-senungeng. Secara umum assenu-sennungeng dimaknai sebagai simbol-simbol tertentu dalam berbagai upacara atau ritual. Simbol-simbol tersebut dimaksudkan sebagai doa mencari berkah dan mengharapkan keberuntungan. Salah seorang pimpinan Pesantren Mazratul Akhirah, K.H. Lukmanul Hakim, menyatakan, upacara-upacara ritual yang menghadirkan simbol-simbol tertentu sebagai bagian dari mengharap kebaikan dari Allah, sejatinya juga telah dilakukan oleh Rasulullah SAW. Karena itulah jika ada tradisi orang Bugis yang berkenaan dengan haji yang melakukan ritual tertentu dengan maksud asennu-senungeng, sebenarnya bukanlah sesuatu yang perlu dipersoalkan. Kecuali jika secara meyakinkan kita menemukan unsur kemusyrikan dalam upacara tersebut.

Dalam proses berhaji orang-orang Bugis, assenu-senungeng dapat dilihat dalam dua hal. Pertama; keseluruhan rangkaian ibadah selama dalam proses berhaji selalu terkait dengan assenu-senungeng. Bagi orang Bugis dalam setiap pelaksanaan hukum kewajiban atau pun sunah haji, tidak hanya dilakukan untuk sekedar memenuhi syarat sah, rukun haji ataupun memenuhi tuntunan manasik haji, tetapi juga selalu ada simbolsimbol pengharapan mendapatkan rida, rezeki dan kebaikan tertentu. Itulah sebabnya, berbagai rangkaian dalam ibadah tersebut, biasanya selalu diikuti dengan kegiatan yang terkait dengan assenu-senungeng.

Ada banyak contoh mengenai hal ini, di antaranya soal anjurkan berdoa menghadap Mizab Arrahmah atau lebih dikenal oleh orang-orang Bugis dengan istilah jompi ulaweng (talang emas). Doa di tempat itu dikenal mustajab. Tetapi bagi orang Bugis tidak cukup doa, air yang jatuh dari jompi ulaweng itu adalah simbol doa dan berkah. Tidak heran jika orang-orang Bugis berlombalomba menadah air dari jompi ulaweng. Dulunya, dapat dilakukan Ketika Ka'bah sedang dicuci dan diganti kiswahnya (kain penutupnya). Tetapi karena kini Ka'bah baru dicuci setelah jemaah haji telah ada di Arafah, maka harapan satu-satunya untuk bisa menadah air dari jompi ulaweng adalah saat hujan. Menadah air dari jompi ulaweng ini adalah assenu-senungeng.

Orang Bugis juga meyakini bahwa kiswah (kain pembungkus) Ka'bah juga dapat dijadikan asenu-senungeng. Dalam kepercayaan orang Bugis, kiswah ini adalah simbol daya tarik. Ia ibarat magnet yang menarik jutaan umat Islam datang kepadanya. Bagi beberapa nelayan Bugis meyakini, jika potongan kiswah ditaruh di kail atau jaring, maka akan menjadi magnet bagi ikan-ikan. Bagi pedagang, jika ditempatkan di tokotoko, kiswah menjadi magnet bagi orangorang untuk datang belanja. Karena itulah ada beberapa dari jemaah haji Bugis, kadangkadang menggunting kiswah Ka'bah secara diam-diam. Kiswah di sini tentu bukanlah dianggap pemberi rezeki tersebut, tetapi ia menjadi simbol doa kepada Allah, agar rezeki seseorang menjadi lancar.

Kedua, assenu-senungeng dikaitkan dengan seluruh ritual lokal yang terkait dengan pelaksanaan haji. Ritual-ritual lokal yang disebut dengan assalama (Selamatan) 
ini, dimaksudkan sebagai bagian dari doa-doa pengharapan pada yang Maha Kuasa. Dalam ritual tersebut selalu muncul simbol-simbol tertentu yang menunjukkan adanya pengharapan tertentu. Simbol itu dapat terlihat dalam makanan yang disajikan, bendabenda tertentu yang ditempatkan dalam upacara maupun dalam bentuk pembacaan barzanji.

Upacara ritual haji yang dipenuhi simbol asenu-senungeng ini, nyaris menjadi kewajiban yang dilakukan oleh masyarakat Bugis, khususnya mereka yang berlatar belakang rural-agriculture. Seperti yang telah dijelaskan di muka, ritual semacam ini memang terbiasa mereka lakukan dalam upacara yang terkait dengan pertanian dan siklus hidup manusia, jauh sebelum datangnya Islam. Karena itu dalam upacara assalama dengan berbagai variannya tersebut, kita akan menemukan pula sebuah proses pergumulan antara Islam dan tradisi lokal dalam masyarakat Bugis.

Penulis tidak bisa mendedahkan satu persatu dari ritual lokal haji tersebut karena keterbatasan ruang. Tetapi ada beberapa bentuk ritual lokal yang bisa penulis uraikan dalam tulisan ini. Salah satunya ritul yang disebut dengan massalama-mammanasik. Ritual ini dari namanya saja telah menggambarkan bahwa yang dilakukan adalah upacara selamatan sekaligus melakukan manasik haji. Dalam acara ini memang dilakukan ritual assalama haji, sekaligus menghadirkan salah satu tokoh agama untuk menjelaskan manasik haji.

Sebagaimana halnya dalam ritualritual lain yang sering dilakukan di Segeri, misalnya ritual mappalili (ritual turun ke sawah), dalam ritual assalama mammanasik disajikan pula beberapa makanan dan buahbuahan. Di antaranya buah pisang setandan, nasi ketang tiga warna (putih, kuning dan hitam) dengan sebutir telur di atasnya, ayam, daging sapi dan ikan goreng bandeng. Dalam ritual selamatan ini selalu dihadirkan penganan tujuh rupa, yakni: cucuru bayao, sawalla, onde-onde, beppa oto', beppa peca, katirri sala dan pejja-pejja. Dalam upacara yang lain mungkin jenis kudapannya berganti, tetapi tetap tujuh jenisnya. Selain makanan, yang tidak terlupakan adalah segelas air putih.
Kadang air putih itu ditaruh di mangkuk, bukan di gelas.

Sajian berbagai makanan dan kue-kue tersebut itulah yang mengandung assenusenungeng. Pisang satu sisir misalnya, adalah harapan agar yang akan berhaji tetap diberikan rezeki dan kesehatan yang bersisir-sisir. Sebutir telur, artinya semoga orang yang akan berangkat haji memiliki keyakinan mallebu tello (membulat seperti telur). Sementara selalu disediakan tujuh macam penganan, maksudnya agar yang melakukan ritual itu nipasituju-tujui, artinya apa yang diharapkannya selalu tercapai secara pas, tidak berlebih-lebihan tetapi juga tidak kurang.

Keseluruhan makanan tersebut diletakkan berjejer di depan tas atau koper yang akan digunakan membawa bekal naik haji. Keberadaan makanan tersebut, dulunya dalam ritual lain, biasa dilengkapi dengan darah binatang. Darah binatang tersebut memang diperuntukkan untuk persembahan pada to tenri ita (makhluk gaib) yang dianggap sebagai penjaga kampung. Persembahan darah dan makanan dalam satu ritual dianggap sebagai cara untuk membujuk makhluk to tenri ita, agar tidak menimbulkan masalah.

Setelah kedatangan Islam, darah binatang sebagai persembahan dihilangkan. Menurut keterangan salah seorang tokoh adat bernama Puang Ali, darah binatang diganti dengan pembacaan barzanji. Pergantian corak ritual itu dilakukan karena persembahan darah kepada to tenrita tujuannya adalah semacam hadiah kepada makhluk tersebut, agar permohonan bisa diterima. Sementara dalam Islam, hadiah itu sepantasnya tidak dikirimkan pada makhluk to tenri ita, tetapi kepada Nabi Muhammad SAW dalam bentuk selawat. Karena itulah dibacakan barzanji yang berisikan salawat kepada Nabi Muhammad SAW. Jadi kalau sebelumnya, yang jadi tawassul (perantara) doa agar diterima adalah dengan mengirim hadiah darah binatang kepada mahluk to tenri ita, setelah kedatangan Islam diganti dengan mengirim selawat kepada Nabi Muhammad SAW.

Sementara air putih, juga merupakan hal yang tidak terpisahkan dari ritual orangorang Bugis. Meletakkan air putih dalam sebuah ritual sudah dilakukan oleh orang 
Bugis sebelum datangnya Islam. Air ini bermakna sumber kehidupan. Dulunya, sebagaimana dijelaskan Halilintar Latief (2004), air yang digunakan dalam satu ritual diambil dari sumur yang dianggap keramat. Nama sumur itu beragam, misalnya: Bungung Barania, Bungung Marajae, Bungung Bissue dan Uwae TuwoE . Sekarang memang tidak mesti lagi diambil dari sumur-sumur semacam it u, tetapi substansi air yang dihadirkan dalam ritual assalama-mammanasik, tetap sama, yakni sebagai simbol bagi yang melakukan acara untuk tetap matuwo (hidup dan mendapatkan sumber kehidupan).

$$
\text { Proses assalama-mammanasik }
$$

dimulai dengan pembacaan doa oleh sanro wanua. Sanro wanua ini adalah orang yang dianggap memahami seluk beluk ritual yang dilakukan di satu kampung. Dalam ritual assalama-mammanasik yang penulis saksikan, sanro wanua itu sekaligus juga adalah guru kampung. Ini berarti bahwa yang bersangkutan selain mengerti ritual-ritual tradisi, juga dianggap paham dengan ajaran Islam.

Sanro Wanua ini pun mematri diri di depan makanan yang tersaji. Tangannya mengambil sejumput dupa lalu menaburkan di at as bara api. Bau harum semerbak mengitari ruangan. Tangannya ditengadahkan ke langit, mulutnya komat-kamit membaca doa. Lamatlamat terdengar Ia membaca pujian pada Allah SWT, lalu selawat kepada Nabi Muhammad SAW, selanjutnya doanya makin sayup dan tidak terdengar lagi.

Sanro berdoa selain menggunakan doa-doa dalam bahasa Arab, sering kali juga mencampur dengan mantra-mantra lokal yang berbahasa Bugis. Kadang pula mengambil dari doa-doa Islam atau meminjam nama-nama dari Islam, tetapi diekspresikan dengan cara lokal. Salah satu ritual haji yang bernama mallise tase (ritual mengisi tas jemaah haji) doanya adalah tasbih, tahmid dan takbir masing-masing sebanyak 33 kali, lalu membaca mantra dengan menyebutkan nama Wali Pitue (wali tujuh). Penyebutan Wali Pitue ini jelas adalah suplementasi lokalitas terhadap doa Islam. Meskipun belakangan penulis diberi tahu Wali Pitue yang dimaksud itu adalah menyebut tujuh nama dari ashabul kahfi, yaitu: Tamlikha, Maksalmina, Martunis, Nainunis, Sarbunis, Falyastatyunis dan Dzununis

Ketika proses berdoa tengah berlangsung, sebenarnya telah hadir pula seorang ustaz yang akan membawakan manasik. Tetapi saat giliran berdoa, yang melakukan tetap si sanro wanua tersebut. Di sini terlihat bagaimana keseimbangan aktoraktor yang berperan dalam acara assalamamammanasik ini. Antara sanro wanua yang merupakan representasi agen dari tradisi lokal, dengan ustaz yang merepresentasikan Islam, sama-sama punya peran dan fungsi.

Setelah doa dilakukan oleh sanro wanua, maka barzanji pun digelar. Yang memimpin kali ini adalah ustaz. Cara membaca barzanji ini khas. Nadanya dan cara membacanya disesuaikan dengan irama lokal. Sering kali panjang pendek pada setiap akhir bait ditambahkan dengan cara tersendiri oleh si pembaca barzanji, disesuaikan dengan nada lokal tersebut. Pada saat itu keselarasan antara cara membaca dengan makna yang dibacanya menjadi tidak penting lagi.

Masuknya barzanji mewarnai ritual lokal orang Bugis ini, jelas menunjukkan adanya pengaruh dari Islam. Bahkan menurut Thomas Gibson (2009) barzanji telah hadir nyaris di seluruh relung ritual masyarakat Bugis-Makassar. Mantra-mantra kuno atau pun persembahan darah binatang disubstitusi dengan cerita yang mengandung doa dan pujian pada Baginda Nabi Muhammad SAW.

Perlu digaris bawahi, kendati barzanji mewarnai ritual lokal tersebut, tetapi barzanji pun harus menerima dibaca dan diungkapkan sesuai dengan langgam lokal. Di saat yang sama posisi barzanji yang sejatinya adalah sejarah Nabi Muhammad SAW pun telah bergeser. Ia tidak lagi berposisi sebagai sejarah nabi, tetapi sudah menjadi salah satu bagian dari assenu-senungeng. Barzanji menjadi simbol pengharapan berkah atau setidaknya menjadi simbol perantara agar keinginan yang melakukan ritual terpenuhi.

Perjumpaan Islam dan tradisi lokal, melalui ritual assalama-mammanasik ini menunjukkan adanya adaptasi tradisi lokal terhadap ajaran Islam. Tradisi lokal terbuka untuk melakukan perubahan-perubahan dalam 
beberapa corak ritualnya demi menerima unsur-unsur Islam. Di sini berlaku apa yang disebut oleh Pieterse (1995) sebagai proses translocal, yakni ketika tradisi lokal itu membuka diri terhadap kebudayaan yang berasal dari luar dirinya. Tetapi tradisi lokal juga tidak menjadi objek yang pasif. Tradisi lokal, melalui agen-agennya, melakukan semacam rereading dan reposisi terhadap tradisi Islam yang diterimanya. Inilah yang disebut dengan sebuah proses encounter, yakni pergumulan dua tradisi melalui satu relasi kuasa, di mana dalam proses pergumulan tersebut terjadi proses negosiasi, kadang-kadang keselarasan, sering pula adaptasi, tapi tak jarang juga saling beresistensi yang mengakibatkan satu entitas harus merelakan kehilangan nilai-nilai tertentu pada dirinya.

Ritual massalama-mammanasik yang dilakukan di banyak tempat di Segeri terlihat semarak. Masyarakat yang datang juga cukup ramai. Ornamen-ornamen upacara ritual juga terlihat lengkap. Tentu hal ini ditunjang dengan kebiasaan mereka melakukan ritual yang terkait dengan siklus hidup dan pertanian. Selain itu, yang menunjang ritualritual lokal haji di Segeri berlangsung cukup semarak karena mereka memiliki collective conscience yang kuat. Menurut Emile Durkheim (1982), kesadaran kolektif yang kuat memang dimiliki oleh masyarakat ruralagraris. Indikator kesdaran kolektif yang kuat ini dapat dilihat dalam upacara ritual. Untuk melihat itu, Antony Giddens (1972: 77-79) mengembangkan empat barometer.

Pertama soal intensitas; yaitu sejauh mana keseriusan dan kesungguhan dalam mengikuti proses ritual. Bagi masyarakat Segeri, ritual-ritual itu terlihat begitu penting, sakral dan orang-orang mengikuti prosesinya secara sungguh-sungguh. Karena penting, maka ritual itu menjadi sesuatu yang tidak boleh ditinggalkan. Kedua, Volume atau banyaknya orang yang hadir. Dalam beberapa perayaan massalamak mammanasik yang penulis saksikan, orang-orang cukup ramai mendatangi tempat upacara. Ketiga, Rigiditas, yakni ketaatan terhadap aturan ritual dan mengikuti seluruh persyarat an ritual yang ada. Sebagaimana digambarkan dalam ritual massalama mammanasik, ritual yang berlangsung juga cukup rigid. Memang ada perubahan beberapa ornamen dan cara pelaksanaan ritual, tetapi secara prinsip masih mengikuti aturan ritual lokal yang ada di Segeri. H. Supu, seorang haji dan tokoh masyarakat di daerah Segeri menyebutkan ritual haji yang tidak mengikuti at uran secara baik, tidak akan mendapatkan berkah. Keempat; Konten dari ritual. Hal ini berkaitan dengan nilai yang diusung dalam ritual tersebut dan ornamen yang melengkapi ritual. Nilainya sebagaimana yang tela diuraikan sejak awal adalah ingin mendapatkan assenusenureng. Untuk hal itu, masyarakat Segeri yang melakukan acara ritual haji ini, seragam dalam memandangnya.

\section{Fenomena Haji Bawakaraeng dan Calabai Naik Haji}

Selain praktik ritual haji yang menunjukkan perjumpaan antara Islam dan tradisi lokal yang harmonis dan selaras, di Segeri muncul pula satu tradisi berhaji yang menimbulkan kesan hajinya tidak seirama dengan haji yang dilakukan secara umum. Hal ini tercermin dalam dua tradisi haji masyarakat Bugis-Segeri, yakni Haji Bawakaraeng dan Calabai Naik Haji.

Haji Bawakaraeng adalah sebutan yang disematkan pada orang-orang yang memiliki kebiasaan naik di Bawakaraeng melakukan salat Idul Ad'ha, yang waktunya kebetulan berlangsung pada musim di mana sebagian umat Islam sedang melaksanakan haji di Tanah Suci Mekkah. Di Pangkep sendiri, terdapat empat daerah yang beberapa masyarakatnya dianggap bagian dari komunitas Haji Bawakaraeng, yakni Segeri, Mandalle, Ma'rang dan Labbakkang. Seorang tokoh lokal bernama Puang Wali adalah pinati sekaligus orang yang sering mengant ar jemaah ke Bawakaraeng. Puang Wali wafat pada tahun 2009. Tetapi hingga kini kebiasaan naik ke Bawakaraeng itu tetap dilakukan.

Naik ke Bawakaraeng, bagi masyarakat di Segeri tidak otomatis sama dengan naik haji. Puang Walli menjelaskan bahwa orang naik ke Bawakaraeng dengan beberapa tujuan: melaksanakan salat Idul Ad'ha; menyepi untuk mendalami ilmu dan mendekatkan diri pada Tuhan; memenuhi nazarnya; dan sebagian bertujuan menyempurnakan ibadahnya, setelah berhaji ke Mekkah. Ada pula yang beranggapan 
bahwa naik ke Bawakaraeng akan mendapatkan pahala haji yang sama dengan pahala naik ke Tanah Suci. Tetapi yang beranggapan seperti ini menegaskan bahwa setelah naik ke Bawakaraeng tidak otomatis bisa menggantikan ibadah haji ke Mekkah.

Dalam masyarakat Bugis-Makassar, naik ke gunung melakukan ritual adalah kebiasaan yang sering dilakukan sebelum datangnya Islam. Mereka meyakini Tokammayya Kananna (Yang Titahnya Pasti Terlaksana) bersemayam di puncak-puncak gunung. Menurut komunitas yang sering naik ke Bawakaraeng ini, seperti Puang Wali dan Munte, dulunya orang-orang naik ke Bawakaraeng bukanlah dalam rangka menyembah, tetapi hanya satu cara untuk menjalin hubungan dan menyapa sesama makhluk Tuhan. Kebiasaan tersebut dilakukan untuk menjaga keseimbangan kosmologi.

Setelah masuknya Islam, kebiasan naik ke Bawakaraeng ini tidak sirna. Komunitasnya malah menyelaraskan dengan ajaran Islam. Jadilah kebiasaan naik ke Bawakaraeng itu dilakukan pada saat Idul Ad'ha. Mereka pun menjalankan salat Idul Ad'ha di tempat itu. Istilah Haji Bawakaraeng sendiri adalah satu bentuk ejekan dari orang-orang di luar komunitas Bawakaraeng. Gelar Haji Bawakaraeng memersilkan adanya perilaku aneh, lain, keluar dari pakem, bahkan sesat. Konstruksi identitas ini, direproduksi terus menerus oleh para peneliti, media, pemerintah dan agamawan.

Lama kelamaan istilah Haji Bawakaraeng ini melekat pada orang-orang yang terbiasa naik ke Bawakaraeng. Merujuk pada istilah Manuel Castells (2003: 8), proses ini disebut sebagai legitimizing of identity, sebuah proses labeling sekaligus pengabsahan satu identitas terhadap komunitas atau kelompok pinggiran dalam satu masyarakat.

Namun komunitas Bawakaraeng juga tidak menjadi objek yang diam. Komunitas ini juga melakukan, sekali lagi meminjam istilah Castells (2003: 8), resistance of identity. Pelabelan yang peyoratif justru diserap menjadi identitas. Tetapi sebelum menyerap mereka memberi makna yang lain terhadap Haji Bawakaraeng. Haji Bawakaraeng bagi mereka menunjukkan adanya semangat dan keikhlasan melakukan perjalanan untuk menjalankan satu ritual. Haji Bawakaraeng mereka juga maknai sebagai cara orang yang tidak mampu menjumpai Tuhannya. Haji Bawakaraeng juga adalah cara menyepi untuk mendekat pada pencipta alam semesta, dan seterusnya. Singkatnya, Haji Bawakaraeng dari istilah yang peyoratif, diubah maknanya menjadi positif.

Untuk semakin mendekatkan antara ritual haji ke mekkah dengan naik ke Bawakaraeng, mereka meniru nama-nama tempat di sana dengan istilah Islam dan beberapa tempat di Mekkah. Ada istilah siratal mustaqim, yaitu jalan setapak yang ada di sisi tebing yang curam. Jelas ini mengambil nama istilah siratal mustaqim, jembatan di akhirat dalam ajaran Islam. Ada pula yang disebut dengan Bakkah. Nama ini disematkan pada satu batu yang berbentuk tugu yang ada di puncak Bawakaraeng. Nama it u meniru dari kata Ka'bah yang ada di Mekkah dan menjadi tempat orang melakukan tawaf pada saat berhaji.

Dalam istilah Bhaba, mereka melakukan peniruan dari kebudayaan atau ajaran yang dianggap universal. Tetapi peniruannya tidak persis sama. Komunitas Bawakaraeng ini mencetak salinan yang kabur (blurred copy) dari Islam. Bhaba lazim menyebut satu kalimat; 'white but not quite [putih tapi tidak cukup (putih)]. Islamnya tidak murni, begitu bahasa kaum puritan dalam melihat komunitas semacam ini. Meniru Islam tapi sekaligus menyempal. Mengikuti tapi pada titik tertentu terlihat subversif (Bhabha, 1997: 152).

'Haji Bawakaraeng' dengan demikian, adalah satu model resistensi dari komunitas lokal. Mereka menjadi bagian dari Islam, mengikuti ajarannya tetapi menggeser beberapa hal dari ajaran tersebut. Haji Bawakaraeng adalah rekonstruksi pengetahuan lokal tentang haji. Michel Foucault (1980:81) mengistilahkan sebagai insurrection of the subjugated knowledges (kebangkitan pengetahuan-pengetahuan yang tertekan). Determinasi dan dominasi dari kebudayaan Islam, mendorong komunitas lokal ini membangun semacam diskursus 
tandingan. Perjumpaan antara Islam dan tradisi lokal dalam konteks Haji Bawakaraeng ini pun terlihat bukan membangun keselarasan, tetapi sebaliknya berbentuk resistensi dari kebudayaan yang mengalami tekanan.

Selain "Haji Bawakaraeng,", yang terlihat unik di Bugis-Segeri ini adalah kebiasaan calabai naik haji. Calabai adalah istilah bagi waria di masyarakat Bugis. Calabai merupakan salah satu gender di Bugis, selain laki-laki, perempuan, calalai (perempuan tomboi) dan Bissu. Di Segeri jumlah calabai cukup banyak sebab di daerah inilah pusat kegiatan para Bissu, sementara Bissu sendiri kebanyakan calabai.

Salah satu kecenderungan calabai di Bugis adalah ikut menunaikan ibadah haji. Hal ini telah berlangsung cukup lama. Di antara para calabai yang naik haji itu tidak lain adalah para Bissu. Mereka di antaranya adalah Bissu Haji Saeke. Haji Saeke adalah Puang Lolo di Segeri, selanjutnya ditabalkan menjadi Puang Matoa. Bissu Saeke naik haji ke tanah suci tahun 1997. Ada pula Bissu haji Lecce dari Wajo, Bissu Haji Soleha dari Soppeng, Bissu Haji Daeng Tawero yang merupakan Puang Matoa Bissu di Bone, dan Bissu haji Kanude dari Batu-batu Soppeng (Lathief, 2004: 62-63).

Menurut keterangan, Azizah, Staf Seksi Haji di Kemenag Pangkep, sampai tahun 2019, selalu ada calabai yang naik haji. Dalam administrasi, haji hanya dikenal dua jenis kelamin, laki-laki dan perempuan. Para calabai yang secara biologis adalah laki-laki, dimasukkan dalam kategori laki-laki. Karena itu sejak pendaftaran sampai berangkat ke tanah suci, para calabai ini jadi laki-laki tulen. Busana yang dikenakan adalah busana kaum laki-laki. Di tanah suci, menurut keterangan Alisye (nama samaran), salah seorang calabai yang telah naik haji, mereka juga memakai busana ihram sama dengan laki-laki lainya.

Namun sebagaimana kebiasaan para calabai, mereka tetap melakukan perawatan diri selama berhaji, sebagaimana lazim dilakukan perempuan. Tentu bedaknya tidak setebal biasanya dan bibir juga tidak semerah saat mereka di tanah air, tetapi tetap diberi pelembab. Begitu pulang ke tanah air, para calabai ini ternyata berdandan tidak kalah hebohnya dengan para perempuan. Mereka mulai merias dirinya, meskipun busana yang digunakan masih tetap pakaian laki-laki. Biasanya menggunakan gamis panjang dan berserban, tetapi wajah dilapisi dengan bedak dan segala kosmetik yang bisa membuat paras mereka terlihat berseri-seri.

Alisye menjelaskan bahwa biasanya para calabai juga menggunakan cenning rara (mantra supaya terlihat menawan), sebelum pesawat mendarat. Tujuannya agar mereka saat sampai di tanah air dipandang oleh para penjemputnya memancarkan aura mabarrakka (penuh berkah). Ciri-ciri haji yang mabrur dalam masyarakat Bugis, menurut Eska (nama samaran), salah seorang ketua calabai di Segeri, terlihat mabarakka saat baru tiba di Tanah Air.

Para calabai di Segeri setelah berhaji kebanyakan tidak meninggalkan statusnya sebagai calabai. Termasuk, mereka masih tetap berkecimpung dengan pekerjaannya masing-masing. Yang Bissu tetap menjadi Bissu. Sehari hari tetap bertindak sebagai penjaga arajang (benda yang dikeramatkan) dan memimpin ritual-ritual lokal. Yang indo botting (perias pengantin) tetap menjadi indo botting. Sementara yang dulunya bekerja di salon, tetap bekerja dan bergelut dengan pekerjaannya tersebut.

Alisye yang penulis temui, masih bekerja di salon. Penampilannya masih tetap seperti calabai pada umumnya. Saat ketemu dengan penulis, ia berdandan ala wanita, rambutnya dibiarkan terurai panjang ke belakang. Tetapi menurutnya, setelah berhaji Ia telah berusaha keras menjalankan secara penuh salat, puasa, dan berzakat.

"Kami para calabai selama ini kan dianggap sebagai pembawa sial, makhluk yang dikutuk, tetapi dengan naik haji itu, kami berharap masyarakat mulai memandang kami lebih lunak dan bisa menerima keberadaan kami." Ucap Alisye.

Dalam masyarakat umum memang santer para calabai ini distigmatisasi. Di Segeri, kendati tekanan terhadap calabai tidak terlalu kuat, tetapi stigmatisasi itu masih tetap dilakukan oleh banyak orang. Mereka dipandang manusia yang menyalahi kodrat. Sementara itu karena para Bissu yang juga kebanyakan calabai sering melakukan ritualritual adat, maka oleh sebagian masyarakat mereka dipandang pula sebagai pelaku 
musyrik, penjaga takhayul dan agen khurafat. Puang Matoa Saidi (Pimpinan Bissu saat masih hidup), menyatakan, orang-orang menyampirkan gelar pada para Bissu dan calabai dengan istilah papanre buaja (penyembah buaya).

Tujuan utama calabai naik haji tentu karena mereka juga ingin beribadah dan menunaikan rukun Islam yang kelima. Tetapi bukan itu alasan satu-satunya. Dari uraian Alisye, dan beberapa calabai lainnya, naik haji merupakan pula media negosiasi para calabai dengan Islam, khususnya terhadap umat Islam yang puritan. Dengan berhaji, calabai ingin menepis tuduhan atas mereka sebagai makhluk yang dianggap terkutuk, sering melakukan perbuatan cabul, menggoda suami orang dan macam-macam tuduhan buruk lainnya.

Eska memberi penjelasan tambahan dengan mengatakan calabai memang harus terlihat lebih religius, kalau perlu naik haji, karena banyak upacara-upacara ritual yang terkait agama yang menghadirkan calabai di dalamnya. Eska mencontohkan para Bissu yang kebanyakan calabai itu kadang-kadang diminta memimpin ritual melepas nazar, bahkan dalam ritual assalama (selamatan) haji juga diminta datang mengatur ritual. Dalam acara seperti itu, calabai tentu harus terlihat lebih pantas. Lebih elok lagi kalau calabai yang hadir adalah mereka yang sudah menyempurnakan juga agamanya.

Berkenaan dengan penjelasan Eka ini, Halilintar Latif telah menguraikan peristiwa Bissu atau calabai mengubah penampilannya dalam salah satu ritual mabbissu yang dilakukan oleh seorang haji yang bernama haji Nawir. Saat itu para Bissu tampil dengan pakaian putih-putih, berkopiah dan berserban, sebagaimana layaknya seorang haji (Latief, 2002).

Calabai naik haji merupakan salah satu cara kelompok minoritas, dalam hal ini para bissu dan calabai tetap bisa surfive. Linda Tuhiwai Smith menyatakan hal semacam ini sebagai cara-cara perjuangan kelompok-kelompok minoritas at au sub kultur agar mendapatkan akses ke wilayah di mana kontrol dan representasi sosial dikuasai oleh kelompok-kelompok dominan (Smith, 1999: $35)$.

Setelah berhaji, para calabai ini tetap menjadi calabai. Bertubuh lelaki tapi berjiwa perempuan atau dalam bahasa Dede Utomo (1996: 261), “woman trapped in men's body". Bedanya setelah berhaji, mungkin mereka merasa lebih aman dengan status kehajian tersebut. Mereka telah berusaha menjadi manusia religius. Setidaknya hal itu meringankan beban mereka dari tatapan melecehkan sebagian masyarakat.

\section{Haji Sebagai Gaya Hidup}

Setiap tahun jika musim haji tiba, di masyarakat Bugis selalu beredar foto-foto jemaah haji, khususnya perempuan, yang tampil glamor. Dalam foto yang tersebar di media sosial tersebut, haji perempuan dari Bugis itu tampil dalam busana khas haji dari Bugis. Cipo-cipo (topi haji yang berbentuk bundar) dengan benang emas, lalu cipociponya dibalut lagi dengan talili (kerudung yang dilingkarkan sedemikian rupa) dan tidak lupa seluruh perhiasan emas di pasang di beberapa bagian tubuhnya. Satu penampilan yang dianggap sempurna dan menunjukkan kelas sosial tersendiri di masyarakat Bugis.

Di masyarakat Bugis, memiliki emas yang banyak adalah satu gaya hidup sosial tersendiri. Emas adalah tanda bahwa yang bersangkutan adalah to sugi (orang kaya). Kini tidak hanya emas, status sebagai haji pun muncul sebagai gaya hidup yang melengkapi identitas to sugi. Karena itu tampil dengan simbol-simbol haji, apalagi ditunjang dengan emas di sekujur tubuh akan menunjukkan eksistensi seseorang dalam lingkungan masyarakat.

Gaya hidup tidak semata, seperti dikatakan David Chaney (1966: 40), sebagai pola hidup yang membedakannya dengan kelompok lain, tetapi juga menentukan ketertarikan dan apa yang dianggap penting untuk tetap eksis. Dalam masyarakat Bugis, haji adalah bagian penting untuk menunjukkan eksistensi diri itu.

Di masyarakat Segeri para hajilah yang mendapatkan posisi dan peran yang penting. Dalam resepsi perkawinan atau hajatan tertentu, biasanya kalangan haji, 
khususnya haji perempuan, yang tampil di panggung utama. Para haji jadi penjemput tamu. Mereka juga yang dapat posisi terhormat untuk menjemput pengantin keluar dari mobil.

Pada malam mappaccing, para hajilah yang dapat kehormatan untuk melakukan ritual mappaccing. "Cobalah tengok daftar orang-orang yang akan mappaccing saat upacara tersebut berlangsung, maka urutan teratas biasanya adalah para haji." Demikian kata seorang perempuan yang sudah sepuh, dalam satu acara selamat an haji. Perempuan tua yang tak mau disebut namanya ini rupanya adalah seorang jannang yaitu ahli mengatur acara-acara ritual tertentu.

Karena haji telah menunjukkan eksistensi masyarakat kelas menengah muslim, maka dalam satu pesta, tidak mungkin menemukan para haji ini bergelut di dapur. Dapur adalah tempatnya para perempuan yang belum berhaji, sementara para haji, tempatnya adalah di panggung depan.

Hal inilah yang menjadikan seorang perempuan di satu pesta di Segeri pernah mengeluarkan ungkapan "Taroni...purapa menre haji na ia tosi riolo sebagai pejemput tamu" [Biarlah begini (saya yang kerja di dapur) nanti setelah saya naik haji, saya lagi yang akan berada di depan menjemput tamu](Wawancara Seorang Perempuan di Segeri, 2017) .

Gaya hidup telah menjadi bagian tak terpisahkan dari masyarakat modern. Tetapi tidak menutup kemungkinan hal ini juga menjangkiti sebagian masyarakat pedesaan atau masyarakat yang masih kuat semangat komunalitasnya. Dalam tulisan Asma Luthfi (2006), modernitas yang menjangkau sampai ke masyarakat pedesaan, telah melahirkan apa yang disebutnya dengan haji modereng. Hal yang sama juga terlihat pada sebagaian masyarakat Bugis yang tinggal di beberapa kampung di Segeri, mereka juga terjangkiti gaya hidup masyarakat modern.

Dalam masyarakat pedesaan kebiasaan melakukan perayaan atau ritual yang melibatkan kerumunan orang, menjadi sarana untuk menunjukkan gaya hidup tertentu dari kelas menengah. Haji menjadi semacam kode sosial tertentu atau menjadi medium untuk mengkomunikasikan gaya hidup kelas menengah ke komunitasnya.

Haji yang menjadi gaya hidup di pelosok Bugis semacam Segeri ini, tentu tidak muncul tiba-tiba. Peran-peran travel dan birobiro haji yang mengiklankan haji melalui agen mereka, ikut mengubah perspektif masyarakat desa tentang haji. Seperti yang dikemukakan Hartini Tahir, dalam beberapa tahun terakhir ini, Biro-biro Haji bermunculan bak cendawan di musim hujan, tak terkecuali di Sulawesi Selatan. Data Kantor kementerian agama provinsi Sulawesi Selatan 2016, seperti dilansir dalam tulisan tersebut, menyebutkan, travel yang terdaftar secara resemi sebanyak 72 unit usaha. Travel itu tersebar ke berbagai daerah di Sul-sel (Hartini Tahir, 2016). Agennya adalah jemaah haji itu sendiri yang menggaet calon-calon jemaah haji lainnya sampai ke pelosok desa. Bila para agen-agen ini berhasil mendapatkan sekian banyak calon jemaah haji atau umrah, ia akan mendapat bonus. Salah satu bonusnya adalah berhaji at au umrah secara gratis.

Model-model bisnis beberapa travel itu menggunakan model ponzi yang berkedok Multi Level Marketing (MLM). Dalam model ponzi ini, owner menarik investor, dalam hal ini jemaah haji atau umrah, dengan imingiming harga murah dan akan mendapat keuntungan yang banyak. Padahal harapan yang dibangun itu palsu, karena sebenarnya uang yang digunakan tak lain adalah uang dari jemaah haji yang bersangkutan. Yang mendaftar awal mungkin berhasil dan menyenangkan karena dapat harga murah sekaligus bonus, tetapi semakin ke belakang akan semakin rugi. Dalam kasus beberapa travel haji dan umrah di Indonesia, seperti First Travel dan Abu Tours, akhirnya jemaah umrah dan haji yang mendaftar belakangan nasibnya terkatung-katung. Akhirnya dua travel itu dibekukan, sementara jemaah haji dan umrah yang mendaftar belakangan tidak bisa berangkat lagi.

Dalam proses menarik jemaah haji atau umrah sebagaimana yang ditunjukkan First Travel dan Abu Tours, tawaran-tawaran perjalanan haji ini bukan lagi sekedar pergi ibadah, tetapi juga sebagai bentuk bisnis, ajang rekreasi dan sekaligus menjual gaya hidup mewah kelas menengah muslim. Orangorang banyak tertarik karena janji bonusnya, 
keuntungan bisnis, dan ada paket jalan-jalan ke beberapa negara. Travel semacam ini telah melahirkan, meminjam istilah Baudrillard (2013), simularka haji. Apa yang dimaksud simularka haji atau umrah ini? Tidak lain ketika haji dan umrah itu telah dimanipulasi oleh kapitalis sebagai sesuatu yang memiliki nilai yang berbeda dari sifat dasarnya. Jika galibnya haji adalah ibadah dan rukun Islam yang kelima, maka dengan proses simularka tadi, haji berubah menjadi sarana rekreasi, cara kelas menengah muslim mengisi waktu luang, ajang berbisnis dan bahkan menjadi gaya hidup.

Tentu saja sikap seperti ini tidak menjadi cerminan seluruh haji Bugis, termasuk di daerah Segeri, tetapi sikap yang menjadikan haji sebagai gaya hidup sebagaimana yang diceritakan di atas nyata hadir di tengah-tengah masyarakat. Sikap semacam ini tentu saja juga melahirkan kritikan dari masyarakat lainnya. Selain gelar satire yang disematkan pada mereka semisal haji tambettu (haji tidak sampai), muncul pula cerita-cerita yang mengejek perilaku ini. Bahkan beberapa lagu Bugis muncul memarodikan haji semacam ini. Dua di antara lagu Bugis itu berjudul: "Hajji Cakindi-kindi (Haji Centil)" dan "Hajji Modereng (Haji Modern)". Lagu yang terakhir tersebut diciptakan dan dinyanyikan Arman Dian Ruzandah. Berikut petikan dua bait syair lagunya:

Asera Juta Angke'na

Nangujuang lao Mekka

Luttu galung luttu tana

Nalele cakkindi-kindi

Hajji Modereng asenna

Janda ta'gattung dua ana

Iyami bawang natungka

Serong kiri pecci' monri

\section{PENUTUP}

Sedari awal, Islam dalam masyarakat

Bugis telah mengalami dialog yang intensif dengan tradisi. Dalam satu ungkapan Bugis disebutkan keseimbangan antara adat (tradisi lokal) dengan ajaran Islam dalam memut uskan satu perkara. Demikian kalimatnya:
Assituresenna adek e sarak e, Mappakarajai sarak e ri ade e, Mapakalebbii adek e ri sara e. (Hubungan syara' dan adat dalam memut uskan satu perkara; syara' menghargai adat dan adat memuliakan syara'). Tetapi perjumpaan Islam dan tradisi lokal tidak berlangsung datar. Islam tidak serta merta mengalami integrasi ke dalam sistem sosial Bugis atau sebaliknya dengan segera Islam mengakomodasi tradisi lokal ke dalam ajaranajaran Islam. Proses perjumpaan itu lebih tepat disebut dengan encounter, yakni pergumulan antara ajaran Islam dan tradisi lokal, di mana Islam dan tradisi lokal saling mengisi, beradaptasi dan mengakomodasi satu sama lain, tetapi di saat yang sama, juga saling bernegosiasi, beresistensi bahkan menegasikan. Ada titik temu di aspek tertentu dan ada titik tengkar pada saat yang lain.

Proses encounter, tak pelak menimbulkan sebuah tradisi baru yang hibrid, yaitu sebuah tradisi campuran antara Islam dan lokalitas. Gambaran perjumpaan yang melahirkan tradisi hibrid itu terlihat dalam salah satu ajaran Islam, yakni: "Haji." Praktik haji dalam masyarakat Bugis, memperlihatkan satu proses pergulatan antara ajaran Islam dan tradisi lokal. Dari proses pergulatan ini melahirkan satu tradisi hibrid, yang seperti tergambar dalam tulisan bisa disebut sebagai Haji Bugis atau "Aji Ugi."

Aji Ugi adalah semacam ekspresi Islam ala orang-orang Bugis. Dalam Aji Ugi, orang-orang Bugis melaksanakan ajaran Islam tanpa melepaskan secara ekstrem tradisi lokal yang sudah ada sebelumnya. Di saat yang sama juga tidak mengurung tradisi lokal itu secara ketat agar tidak mengalami perubahan.

Kini haji di tengah orang-orang Bugis tidak hanya mengalami perjumpaan dengan tradisi lokal, tetapi juga sekaligus dengan modernitas. Dalam kehidupan masyarakat Bugis, hingga ke pelosok-pelosok gaya hidup modern juga telah menjangkiti. Tak pelak hal ini mendorong Islam mengalami pergumulan dengan tradisi lokal sekaligus modernitas di sisi yang lain. Perjumpaan dengan modernitas ini memberi corak baru terhadap Aji Ugi. Aji Ugi mulai menyerap salah satu dari cara hidup orang-orang modern, yakni menjadikan haji sebagai salah satu gaya hidup untuk 
membedakan dengan kelompok sosial lainnya dalam masyarakat. Haji menjadi penanda sosial tertentu di Bugis, di samping kebangsawanan (arung), kekayaan (sugi) dan keberanian (warani).

Tentu saja modernitas ini tidak sepenuhnya juga diserap oleh orang Bugis, buktinya perayaan-perayaan lokal yang bersifat tradisional dengan nilai-nilai yang bertentangan dengan modernitas, misalnya bertolak belakang dengan efisiensi dan berseberangan dengan efektivitas, tetap berlangsung semarak. Bahkan haji yang dijadikan gaya hidup oleh sementara orang Bugis, juga mengalami resistensi dari masyarakat Bugis lainnya. Muncullah istilahistilah yang mengejek haji yang semacam itu baik dalam ungkapan satir, humor yang mengejek dan lagu-lagu daerah yang mengkritik secara pedas.

Aji Ugi dengan demikian, tidak lain adalah proses pergumulan antara ajaran Islam, tradisi lokal dan modernitas, yang satu sama lain saling mengisi, beradaptasi dan menyelaraskan nilai-nilai yang dimiliki masing-masing entitas. Tetapi di sisi yang lain juga saling mengoreksi dan meresistensi satu sama lain.

\section{UCAPAN TERIMA KASIH}

Terima kasih penulis sampaikan kepada tokoh masyarakat dan para haji di Segeri, serta Kementerian Agama Pangkep dan KUA Segeri yang telah banyak membantu dalam proses penelitian. Mereka adalah informan yang sangat membantu dalam menyampaikan berbagai data-data yang terkait dengan haji. Tidak lupa ucapan terima kasih pula kepada para pembimbing penelitian dan penulisan, termasuk ikut terlibat dalam penulisan artikel ini, yaitu: Prof. Dr. H. Musafir Pababbari., M. Si, Prof. Dr. H. Muhammad Ramli.,M.Si dan Drs. H. Wahyuddin Halim., M.A., Ph.D. Semoga jasajasa semua yang terlibat, hingga artikel ini dapat selesai mendapat Rahmat dari Allah SWT.

\section{DAFTAR PUSTAKA}

Abdalla, Ulil Abshar. 2019. Manjadi Manusia Rohani. Bekasi: alif.id.

Abdullah, Taufik. 1987. Sejarah Dan Masyarakat, Lintasan Historis Islam Di Indonesia. Jakarta: Pustaka Firdaus \& Yayasan Obor Indonesia.

Abdurrahman, Emsoe. 2016. Hadji Tempo Doeloe. Bandung: MCM Publishing.

Ahmad, Abd Kadir. 2013. "Haji Di Bontonompo Kabupaten Gowa Tinjauan Sosial Ekonomi." Al-Qalam 19 (2): 165-76.

Andaya, Leonard Y. 2004. Heritage of Arung Palakka (Warisan Arung Palakka). Makassar: Ininnawa.

Assael. 1984. Consumer Behavior and Marketing Action. I. Boston Massachuset: Kent Publishing Company.

Baudrillard, Jean. 2013. Masyarakat Konsumsi. Yogyakarta: Penerbit Kreasi Wacana.

Bhabha, Homi K. 1997. "Of Mimicry and Man": The Ambivalen of Colonial Discourse." In Tensions of Empire: Colonial Cultures in a Bourgeois World, edited by Frederick Cooper \& Ann Laura Stoler. Barkeley: University of California Press.

Bruinessen, Martin Van. 1997. "Mencari Ilmu Dan Pahala Di Tanah Suci", Orang Nusantara Naik Haji." In Indonesia Dan Haji, edited by Sudarsono. Jakarta: INIS.

Castells, Manuel. 2003. The Power Of Identity: The Information Age, Economy, Society and Cultural. Vol II. Australia: Blacwell Publishing.

Chaney, David. 1966. Life Style: Sebuah Pengantar Komprehensif. Yogyakarta: Jalasutra.

Durkheim, Emile. 1982. The Devision of Labor in Society. New York: Free Press.

"Ensiklopedi Islam." 1997. Ensiklopedi Islam. Ichtiar Baru Van Hoeve Jakarta.

Fenanie, Husnan Bey. 2010. "Haji Dalam Perspketif Al-Qur'an." In Dinamika Dan Perspektif Haji Indonesia, edited by F.M. Rezky. Jakarta: Dirjen Penyelenggaraan Haji dan Umrah Kementerian Agama. 
Foucault, Michel. 1980. Power/Knowledge: Selected Interviews \& Other Writings 1972-1977. New York: Pantheon Books.

Geertz, Clifford. 2017. Agama Jawa; Abangan, Santri Dan Priayi Dalam Kebudayaan Jawa. III. Depok: Komunitas Bambu.

Gennep, Arnold Van. 1960. The Rites of Passage. London: Routledge \& Kegan Paul.

Gibson, Thomas. 2009. Kekuasaan: Raja, Syeikh Dan Ambtenaar. Makassar: Ininnawa.

Giddens, Anthony. 1972. "Introduction: Durkheim's Writings in Sociology and Social Philosophy"." In Emile Durkheim: Selected Writing, edited by Anthony Giddens. Cambridge: Cambridge University Press.

Gordon, Milton. 1964. Assimilation in American Life. New York: Oxford Unversity Press.

Kemenag-Sulsel. 2018. "Data Haji Kementerian Agama Sulsel." Makassar.

Koentjaraningrat. 2007. Sejarah Teori Antropologi I. Jakarta: Universitas Indonesia.

"Kronologi Nurjannah Tertangkap Gunting Kiswah.” 2018. Liputan 6.Com. 2018.

Lathief, Halilintar. 2004. Bissu; Pergulatan Dan Peranannya Di Masyarakat Bugis. Depok: Desantara.

Latief, Halilintar. 2002. "Bissu: Tradisi Tranvestites Shammans Bugis." In Simposium Internasional III. Bali.

Loir, Henri Chambert. 2013. Naik Haji Di Masa Silam; Kisah-Kisah Orang Indonesia Naik Haji. Jakarta: KPG.

Luthfi, Asma. 2006. “Aji Modereng: Studi Tentang Haji Dan Perubahan Sosial Budaya Dalam Masyarakat Bugis.” Universitas Gadjah Mada.
Oetomo, Dede. 1996. Masculinity in Indonesia: Genders, Sexualities, and Indentities in Changing Society, in Framing the Sexual Subject: The Politics of Gender, Sexuality and Power. Barkeley: University of California Press.

Pangkep Dalam Angka. 2019. Pangkep: BPS.

Parekh, Bikhu. 2000. Rethinking Multiculturalism: Cultural Diversity and Political Theory. London: Mc.Milan.

Pieterse, J. 1995. "Globalization as Hybridization' in M.Featherstone." In Global Modernities, edited by R.Robertson S. Lash \&. London \& Newbury Park: CA: Sage.

Putuhena, Shaleh. 2007. Historiografi Haji Indonesia. Yogyakarta: LKiS.

Saerozi, H. Moh. 2008. Orang Indonesia Berhaji. Jakarta: Titian.

Salim, Hairus. 2018. "Haji Dalam Masyarakat Banjar." Https//Haisa.Wordpress.Com. 2018.

Seksi Haji Kemenag Pangkep. 2018. "Data Haji Pangkep." Pangkep.

Smith, Linda Tuhiwai. 1999. Decolonizing Methodologies: Research Indigenous Peoples. London: Zed Books.

Tahir, Hartini. 2016. "Haji Dan Umrah Sebagai Gaya Hidup: Pertumbuhan Bisnis Perjalanan Suci Di Kota Makassar." Al-Qalam 22 (2): 127-39.

Vredenbregt, Jacob. 1997. Ibadah Haji: Beberapa Ciri Dan Fungsinya Di Indonesia. Jakarta: INIS.

Weber, Max. 1930. The Protestant Ethic and the Spirit of Capitalism. London \& Boston: Unwin Hyman. 